\title{
A Case Study of a Foreign Language Learner with Severe Learning Problem: The Role of Anxiety
}

\author{
Farid Ghaemi \\ Islamic Azad University, Karaj Branch, Iran \\ Email: ghaemi@kiau.ac.ir \\ Naeemeh Kharaghani \\ Islamic Azad University, Science and Research Branch, Tehran, Iran \\ Email: naeemehkharaghani@gmail.com
}

\begin{abstract}
This study is a case study of a foreign language learner with severe learning problem. After selecting the subject, he was interviewed by the researcher for some sessions. The researcher discussed the items of some valid questionnaires about anxiety. Some parts of the so called interview were taped with the learner's collaboration and consciousness. Then the results were analyzed by classifying the items of the questionnaire and taking into account the cross check items. It was found that the participant was suffering from anxiety in English language classrooms.
\end{abstract}

Index Terms - severe learning problem, learners' feelings, anxiety

\section{INTRODUCTION}

Learners with severe learning problems are every now and then the cases met by EFL teachers in language classrooms. Learning problems are due to different reasons. One of the main reasons goes back to learner's feelings and attitudes. Learners' feelings can act as facilitators or obstacles in the process of language learning. For example, lack of motivation or anxiety would impede the language learning process (Schumann, 2004).

This study deals with a case study of an English language learner who suffers from sever learning problem. The researcher, through applying different questionnaires, found that he was experiencing anxiety in the process of language learning. This paper reports what the researcher did to unfold the reason of his learning problem. In fact it deals with how anxiety was involved in the process of language learning.

Anxiety is always considered as a destructive factor for learners. This kind of anxiety, i.e. debilitative anxiety, is changed into stress and nervous tension. Therefore, many EFL/ESL teachers and testing specialists try to decrease this kind of anxiety since this anxiety may have some crucial effects on EFL learners' performances (Arnold, 2000).

Anxiety is described as a painful emotional condition in which one perceives danger, feels helpless and experiences nervousness in preparation for a probable danger. In general, it is classified into three types: Trait, state and situationspecific anxiety. Trait anxiety is a more stable disposition to be anxious, and is viewed as an aspect of personality. State anxiety is an apprehension that is experienced at a particular moment in time as a reaction to specific situation. Finally, situation-specific anxiety is related to apprehension aroused at specific situations and events (Ellis,2008).

\section{REVIEW OF LITERATURE}

The past twenty years have seen a real increase in the number of studies dealing with anxiety in the L2 domain, which is attributable to the significant advances in the theory and measurement of L2-related anxiety since the mid1980s (Liu, 2006).

Language anxiety is one of the negative factors in SLA. However several studies produced inconsistent results and have not concurred in the sub categorization of language anxiety.

The role played by anxiety in foreign or second language learning is an issue which has long been in the center of attention of language investigators (Horwitz, 1986). As early as in the 1970s, a period noticeable by an increase of research focusing on the learner, anxiety - among other individual learner differences anticipated to affect language learning success - started to be examined as a potential factor influencing L2 achievement (Dornyei, 2005).

According to one study done by Toth (2008) two basic approaches have been considered to the study of anxiety in the L2 domain. These are labeled (1) the anxiety transfer, and (2) the unique anxiety approach, which are reflective of different conceptualizations of L2-related anxiety (MacIntyre et al, 1997).

In the first approach anxiety is considered as the issue experienced in an L2 context and it is basically the transfer of other forms of anxiety into the L2domain. This shows that individuals who are generally apprehensive or experience 
anxiety in certain types of situations are assumed to have a tendency to also experience anxiety when learning or using a foreign language (Saito et al, 1999).

On the contrary, the assumption underlying the other approach states that language learning produces a unique type of anxiety. In this conceptualization, anxiety experienced in L2 contexts is seen as a situation specific anxiety which is aroused by the experience of learning and using a second language.

In another view, MacIntyre and Gardner (1994) stated that anxiety can be considered as one of the best predictors of success in second or foreign language proficiency and this has been investigated in many studies, since language anxiety is one of the internal factors related to learners and it may obstruct the success in language proficiency and generally language acquisition.

Following this study, several other studies (eg. Gardner, 1985 as cited in Oh, 1992) found high correlation between the anxiety and the proficiency i.e. those learners who had low anxiety level were more successful in language learning and vice versa.

In the literature, not just the relationship between anxiety and language learning is searched but also the relationship between test anxiety and academic performance was done in some researches (Hill\& Wigfield, 1984). Test anxiety is a multidimensional construct that has been defined as "the set of phenomenological, psychological and behavioral responses that accompany concern about possible negative consequences or failure on an exam or similar evaluative situation" (Chapell,et al ,2005, p. 17).

And finally according to Graham, (1997) language anxiety integrates three related performance anxiety: 1) communication apprehension 2) test anxiety, 3) fear of negative evaluation. Because of its emphasis on mutual interaction, the construct of communication fear is quite relevant to the conceptualization of foreign language anxiety.

Also it can be said that many variables may interact to affect language learning, but foreign language anxiety should be of considerable concern to language educators and students because of its potential impact, not only on proficiency ,but also on students' affective reactions, hence their attitude toward language learning in general.

Therefore, it is worth mentioning that understanding the effects of language anxiety can help both teachers and learners in the way that teachers can control its effect by improving their teaching and students by using appropriate strategies provided by teachers. So, it is necessary to investigate the characteristics of language anxiety in language learning.

A considerable body of research from the mid-1970s onward shows that communication anxiety generally affects many EFL/ESL learners. Because anxiety may hinder performance and success therefore classroom anxiety is a topic worthy of more exploration.

By taking this fact into consideration that there some types of anxiety, Saville-Troike( 2006) proposed that foreign language anxiety was separate from other kinds of anxieties.

These anxieties can be illustrated in various ways and divided into several classes, which overlap each other somehow. Firstly in general terms is the distinction between trait anxiety, which is the tendency of a person to be anxious or feel stress regardless of the particular conditions, and state (situational) anxiety, which is nervousness or tension at a particular moment in response to some other stimulus.

\section{A. Causes of Foreign Language Learning Anxiety}

One of the most crucial reasons of EFL/ESL anxiety are situational variables, for instance, course activities, course level, course organization, and instructor behavior (Hale,2008)

Another reason is learner variables which includes ability, age, beliefs, gender, learning styles, and personality factors among others (Dornyei\& Skehan, 2003).But some other scholars believe that not two above-mentioned variables but rather it is the native language ability and language learning ability of the learner that need to be taken into account.

\section{B. Characteristics of Foreign Language Learning Anxiety}

There are particular characteristics of formal foreign language learning that hold the potential for irritating anxiety in learners. For example the incapability to pronounce words properly or use correct grammar can cause negative evaluation by others, and the inability to understand spoken and written input, including instructions, can lead to bewilderment and embarrassment about how to respond or how to act. These types of anxiety can contribute to making formal foreign language learning a particular vulnerable experience for many learners.

\section{Effects of Foreign Language Learning Anxiety}

Foreign language learning anxiety has been related to many negative outcomes that can be categorized as physical, psychological, or social (Saville-Troike, 2006).

Physical symptoms consist of speedy heartbeat, muscle tension, dry mouth, and extreme perspiration.

Psychological symptoms consist of embarrassment, feelings of defenselessness, fear, going blank, and poor memory remembrance and retention among others. Negative social behavior may be illustrated in such ways as unsuitable silence, reluctance to take part, non-attendance, and withdrawal from the course. These effects can lead to poor performance and low success. Research suggests that for many learners, success and insistence in foreign language learning considerably depends both on the teacher's ability to reduce the devastating effects of classroom anxiety and the learners' ability to handle the anxiety that cannot be hindered or avoided. 
In contradiction of this debilitative anxiety, there is an indication that a certain degree of anxiety may be useful to learners (Ellis, 2008).This kind of anxiety is usually referred to as facilitative anxiety, it motivates learners to study harder and make stronger efforts to achieve better in classroom. There are some disagreements as to whether this emotional state is really anxiety, or the terms such as attention and alertness may be more precise.

In fact, communicating orally in the foreign language has often been considered by both teachers and learners as more anxiety inducing than the practice of other language skills (Hale, 2008).

In a study which was held in one of the universities of Spain, a translated version of FLCAS was utilized and after participants answer the questionnaire the result shows the existence of considerable levels of anxiety in the foreign language classroom, levels that, in certain items, are even higher than those registered by Horwitz (1986) among groups of beginners. The use of this research instrument with a group of students who had accumulated a long experience as learners of English as a foreign language has allowed us to check that the phenomenon of foreign language classroom anxiety is not necessarily characteristic or exclusive to beginners as seemed to suggest the fact that the FLCAS and other scales devised for a similar purpose had been recurrently applied to groups of beginners in previous research (Horwitz 1986, p.125).

\section{RESEARCH QUESTIONS \& HYPOTHESIS}

1. Does decreasing the EFL learner's level of anxiety have any effect on their language learning process?

2. Does increasing the EFL learner's level of anxiety have any effect on his /her language learning process?

$\mathrm{H}_{\mathrm{O}}$ 1. Decreasing the EFL the learner's level of anxiety has no effect on his/her language learning process.

$\mathrm{H}_{\mathrm{O}}$ 2. Increasing the EFL learner's level of anxiety has no effect on his/her language learning process.

\section{METHOD}

\section{A. Participants}

The participant in this study was an elementary level EFL English language learner. He was 27 years old. He was an undergraduate student of Geology. He was in an urgent need of improving his English language proficiency. He tried hard but he couldn't improve his language proficiency. Although he had already passed some English courses but he was not able to neither speak nor write in English. He was studying English in Hafez Language Institute in Mashhad, Iran. He was reading the New Interchange series $2^{\text {nd }}$ book as the course book in the institute.

\section{B. Instrumentation}

The first instrument used in this study was a language background questionnaire by Ehrman, (1996, p.307) .This was used in order to find out about the biographic background of the participant.

The second instrument was Horwits questionnaire. Horwits foreign language classroom anxiety questionnaire was a likert type scale with five possible responses ranging from "strongly disagree" to "strongly agree" It was meant to evaluate the level of foreign language anxiety experienced by EFL/ESL learners (Horwitz \& Cope 1986 cited in Cebreros, 2001 ).

Another tool used in this study was a motivation and strategies questionnaire (Ehrman, 1996, p.307).Some parts of this questionnaire were directly related to anxiety in language classrooms. This questionnaire was a five point Likert scale ranges from: not at all, not very much, a fair moment, a lot and really nervous about it.

It is worth mentioning that validity of the questionnaires were checked by the researcher. In this regard, the researcher checked each item on a specific construct. It was found that each item dealt with one specific construct.

In addition, another instrument which was used in this study was a voice recorder. The voice recorder was used to auditaped the teacher and the learners' talk during the sessions.

\section{Procedure}

The researchers was supposed to locate an English language learner with sever learning problem. The subject was selected on the ground that he was my student at Mashahd Azad University when he was a BA student of Geology. He had many problems at that time passing the English course for pre-university students. He had failed the course several times.

After selecting the subject, he was interviewed by the researcher for some sessions .During the interview, the researcher discussed the items of some questionnaires about anxiety. It is also worth mentioning that during the process of this investigation, some parts of the so called interview were taped with the learner's collaboration and consciousness.

\section{Data Analysis}

The language learner's responses to different items of the questionnaire were taken into consideration. There were some cross check items on questionnaires that check the validity of the responses.

The instrument used in this study was Horwits questionnaire. The anxiety inventory analysis items could be summarized as follows: (Horwitz \& Cope 1986 cited in Cebreros, 2001). 
TABLE. 1

ITEM ANALYSIS OF FOREIGN LANGUAGE CLASSROOM ANXIETY SCALE

\begin{tabular}{|l|l|l|}
\hline Item Classification & Items & Total number of items \\
\hline Items which address anxiety & $1,3,4,7,9,10,12,13,16,17,19,20,23,26,27,29,31,33$ & 18 \\
\hline Cross check items(show lack of anxiety) & $2,5,11,14,18,22,24,28,32$ & 9 \\
\hline Irrelevant items & $6,15,21,25,30$ & 5 \\
\hline
\end{tabular}

As it was indicated in table 1, there were some irrelevant items on the foreign language classroom anxiety scale. This is usually done in questionnaires to prevent students not to find the purpose of the study.

It was found that the participant responses to items 4,7,9,10,12,13,16,26,27, 31,33 were ranged from mostly strongly agreed or agreed.As it was shown in table 1 , these items address anxiety of foreign language learners in language classrooms and while speaking in foreign language. In the following table, Ehrman, (1996, p.307) questionnaire was analyzed considering its items.

TABLE. 2

ITEM ANALYSIS OF SELF-EFFECACY, MOTIVATION AND ANXIETY QUESTIONNAIRE

\begin{tabular}{|l|l|}
\hline Strategic questionnaire & Items \\
\hline 1. self-efficacy & $1,2,5$ \\
\hline 2.motivation & $3,4,6$ \\
\hline 3. anxiety & 7,8 \\
\hline
\end{tabular}

It should be mentioned that there were some items in the inventory that were not related to anxiety. There were deleted by the researcher since anxiety was the focus of the study. Therefore, those items were not discussed by the researcher with the learner. The participant response to items 7 and 8 of the questionnaire was "a lot" and "really nervous".

Considering the participant response to the items of the questionnaires, hypotheses were rejected since anxiety influenced his performance. Increasing anxiety impeded the performance of the participant.

\section{CONCLUSION}

Through considering the responses of the participant to the items of the questionnaires, it was found that he was suffering from anxiety in English language classrooms. The cross check item also confirmed that the person was experiencing anxiety in English language classroom. He was largely concerned with how others viewed him if he did poorly in the class. It would impede his participation in the class since he was afraid of performing poorly in front of other. Also, he was deeply worried about his own self-image. He didn't feel quite sure of himself when he was speaking in the English class. He expressed panic when he had to speak without preparation in English class.

Therefore it could be concluded that the person's anxiety plays a central role in his ineffective process while learning English. His performance would be improved if this anxiety would be controlled. Knowing about such an issue is very critical for language teachers since they would be able to help the learners to overcome their anxiety and improve their language learning process.

\section{REFERENCES}

[1] Arnold, J. (2000). Seeing through listening comprehension exam anxiety. TESOL Quarterly, 34 (4), 777 - 786.

[2] Cebreros, A.N. (2001). Measuring language anxiety perceived by Spanish university students of English. Retrieved December 2010 from: http://www.publicacions.ub.es/revistes/bells12/PDF/art11.pdf.

[3] Chapell, M. S., Blanding, Z. B., Silverstein, M. E., Takahashi, M., Newman, B., \& Gubi, A. (2005). Test anxiety and academic performance in undergraduate and graduate students. Journal of Educational Psychology, 97,268-274.

[4] Dornyei, Z. (2005). The psychology of the language learner: Individual differences in second language acquisition. New Jersey: Lawrence Erlbaum Associates, Inc.

[5] Dornyei, Z., \& Skehan, P. (2003). Individual differences in second language learning. In C. J. Doughty \& M. H. Long (Eds.), The handbook of second language acquisition, (pp. 589-630). New York: Blackwell Publishing.

[6] Ehrman,M.E.(1996).Understanding second language learning difficulties. London: Sage Publication, Inc.

[7] Ellis, R. (2008). The study of second language acquisition $\left(2^{\text {nd }}\right.$ ed.). Oxford: OUP.

[8] Graham, S. (1997). Effective language learning: Positive strategies for advanced level language learning. New York: Multilingual Matters.

[9] Hill, K. T.,\& Wigfield, A. (1984). Test anxiety: A major educational problem and what can be done about it. The Elementary School Journal, 85,105-124.

[10] Hale, C.(2008). Charting new courses: Second language action research in Japanese junior and senior high school. New York: Accents Asia Press.

[11] Horwitz, E. (1986).Preliminary evidence for the reliability and validity of a foreign language anxiety scale. TESOL Quarterly, $20,559-562$.

[12] Liu, M. (2006). Anxiety in Chinese EFL students at different proficiency levels. System, 34, 301-316.

[13] MacIntyre, P. D \& Gardner, R.C. (1994). The effects of induced anxiety on three stages of cognitive processing in computerized vocabulary learning. SSLA, 4, 1-17. 
[14] MacIntyre, P., Noels, K., \& Clément ,R. (1997). Bias in self-ratings of second language proficiency: The role of language anxiety. Language Learning, 47,265-287.

[15] Oh, J. (1992). The effects of L1' reading assessment methods on anxiety level. TESOL Quarterly, 26 (1), 172 - 176.

[16] Saito, Y., Horwitz, E. K., \& Garza, T. J. (1999). Foreign language reading anxiety. The Modern Language Journal, 83, $202-$ 218.

[17] Saville-Troike, M. (2006). Introducing second language acquisition. Cambridge: CUP.

[18] Schumann, J. H. (2004). The neurobiology of aptitude. In J. H. Schumann, S. E. Crowel, N. E Jones, N. Lee, S. A. Schuchert \& L. A. Wood (Eds.), The neurobiology of learning: Perspectives from language acquisition (pp.23-43). New Jersey: Lawrence Erlbaum Associates, Publishers.

[19] Tóth, Z.(2008). A foreign language anxiety scale for Hungarian learners of English. WoPaLP,2, 55-77.

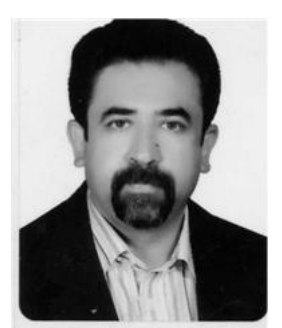

Farid Ghaemi holds a PhD in TEFL from Islamic Azad University, science and research branch, Tehran, Iran. He teaches in Islamic Azad University, Karaj branch In addition, he offers graduate and post-graduate courses in Islamic Azad University, science and research branch, Tehran, Iran .One of his main areas of interest is language learning theories and strategies,. He has already published some articles in the field of language learning and teaching.

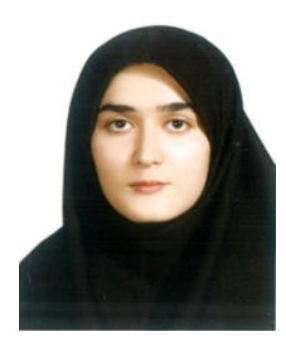

Naeemeh Kharaghai is a PhD student of TEFL at Islamic Azad University, science and research branch, Tehran, Iran. She got her MA in TEFL from Alzahra University of Tehran. Right now, she is teaching in Quchan Azad University. She is interested in language learning, SLA theories and language testing. 